\title{
Excavation of a Neolithic long mortuary enclosure within the Roman legionary fortress at Inchtuthil, Perthshire
}

\author{
G J Barclay* \& G S Maxwell $\dagger$ \\ with a contribution by Coralie Mills
}

\begin{abstract}
The excavation of the eastern half of a rectilinear ditched enclosure was undertaken to provide information on its date, structural details and function. Two fence-like structures had been erected consecutively along the line of the enclosing ditch; the second fence had been burned in situ. Elements of this fence were dated to the late fourthlearly third millennium bc. There were indications of an elaboration of the eastern end of the enclosure. No associated artefacts were found.

Portions of two Roman barrack blocks were revealed, and a legionary axe was recovered from a disturbed pit cut through the eastern end of the ditch of the prehistoric enclosure.
\end{abstract}

\section{INTRODUCTION}

The Roman fortress at Inchtuthil in Perth \& Kinross District, Tayside Region (NO 125 396), was excavated between 1952 and 1965 by Sir I A Richmond and Professor J K St Joseph (Pitts \& St Joseph 1985) (illus 1). The excavation demonstrated that the site of the fortress had also seen funerary and ceremonial activity in the Neolithic and Bronze Age. The most significant pre-Roman feature discovered during the excavation was a trapezoidal enclosure with its long axis aligned east to west and its broader end at the east. Pitts and St Joseph reported that the enclosure was $53.9 \mathrm{~m}$ long, $10 \mathrm{~m}$ across at the east end and $8.4 \mathrm{~m}$ across at the west end and had been defined by a ditch $1.3-1.6 \mathrm{~m}$ wide at the surface and $0.9-1.2 \mathrm{~m}$ deep. The Inchtuthil plans were not drawn on site, but were prepared afterwards from measurements; there are discrepancies in the dimensions and locations of structures and the fence line on figs 75 (the plan of structure) and 81-2 (plans of the south-east and south-west quarters) in the report. Although the present excavation did not include any trenching at the west end, it is believed that the aerial photograph plot combined with the plan of the excavated east end (illus 7) more accurately represents the length of the structure $(50 \mathrm{~m})$.

Four sections and a plan were published in the Inchtuthil report (ibid, 248-50). The plans showed that only a very small proportion of the enclosed area was excavated and that no

* Inspectorate of Ancient Monuments, Historic Scotland, 20 Brandon Street, Edinburgh

$\dagger$ Royal Commission on the Ancient \& Historical Monuments of Scotland, John Sinclair House, 16 Bernard Terrace, Edinburgh 


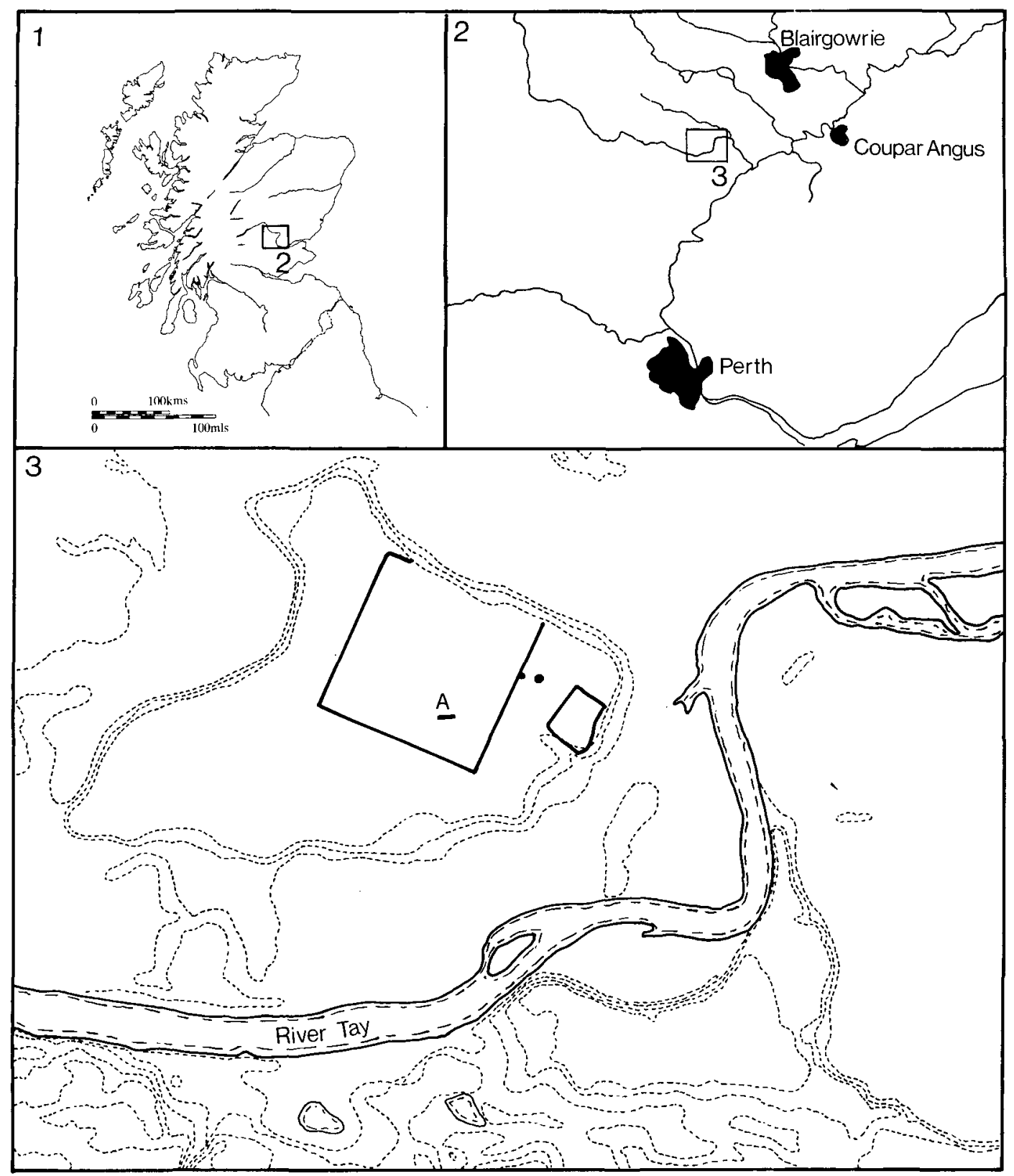

ILlus 1 Location map: A is the long mortuary enclosure, lying within the legionary fortress (rampart shown as a bold line)

features other than the ditch were identified. The sections and the contemporary descriptions suggested that the lower half of the ditch had filled naturally, with, at a level about half way between the ditch bottom and the modern surface, considerable quantities of burnt material.

The monument was interpreted at the time of its discovery as the foundations of a Bronze Age house with a timber roof set in the fill of the ditch at an angle of $40^{\circ}$. The authors 
were consulted by the authors and editor of the Inchtuthil report; as good parallels for the structure had since been identified (Ashbee 1966; Marsac, Scarre \& Riley 1983; Loveday \& Petchey 1982) we suggested that the enclosure belonged to a class of Neolithic structures associated with the long barrow tradition. Specifically, the ditch fills were interpreted as being the remains of a timber structure (perhaps a fence) erected on the inner side of the ditch, which had burned and fallen into the partly filled ditch. The trenches laid out by Richmond and St Joseph over the structure were positioned to investigate the ditch and a portion of the interior totalling some $65 \mathrm{~m}^{2}$ (Pitts \& St Joseph 1985, fig 75). Two of the trenches would not have located prehistoric features, as they were designed mainly to find the post trenches of Roman barracks (which largely filled the small excavated areas). No features were found in the two larger trenches in the interior of the enclosure.

The authors were intrigued by the Inchtuthil structure and by the unusual fills of the enclosure ditch, particularly against the background of the discovery of comparable ditched rectangular or trapezoidal structures in other parts of Britain (Loveday \& Petchey 1982), and decided to undertake more extensive excavation.

The aims of the excavation were as follows:

(a) to locate the enclosure ditch and to excavate sections on the north and south sides, with the intention of examining the deposition processes within the ditch, paying particular attention to the burnt material;

(b) to gather samples for radiocarbon dating and for palaeobotanical analysis (macroplant and pollen);

(c) to gather artefacts for stylistic and possibly residue analysis;

(d) to examine a portion of the interior at the east end to try to locate features associated with the use of the structure;

(e) to examine portions of the interior adjacent to the inner edge of the ditch to try to locate the site of any structure which might have burnt and fallen into the ditch;

(f) to examine an area outside the enclosure, particularly at the east end, where features associated with the use of the structure might be located.

The excavation was undertaken over three weeks in September 1989. An area of about $470 \mathrm{~m}^{2}$ was stripped carefully, using the back acter of a JCB; the area was then hoed and trowelled.

The description and interpretation of the features recovered is presented as follows: first, Prehistoric Features: Description and Interpretation; then the specialist contribution relating to the burnt timbers of the structure by Dr Coralie Mills; followed by Prehistoric Features: Discussion; and Roman Structures and Artefacts. Work is in hand on the pollen from soils in the ditch.

\section{PREHISTORIC FEATURES: DESCRIPTION AND INTERPRETATION}

\section{THE DITCH}

The ditch was the most significant feature noted on the site, $62 \mathrm{~m}$ being exposed. The line of the ditch was clearest on the southern side, where it seemed to have been eroded to a greater degree than on the north side and the east end (where it was additionally obscured by a relict soil). Much of the north ditch was dug through silty sand, which was considerably disturbed by animal burrowing; the interpenetrated ditch-face thus provided insufficient contrast to the fill to allow the difference to be easily detectable. 


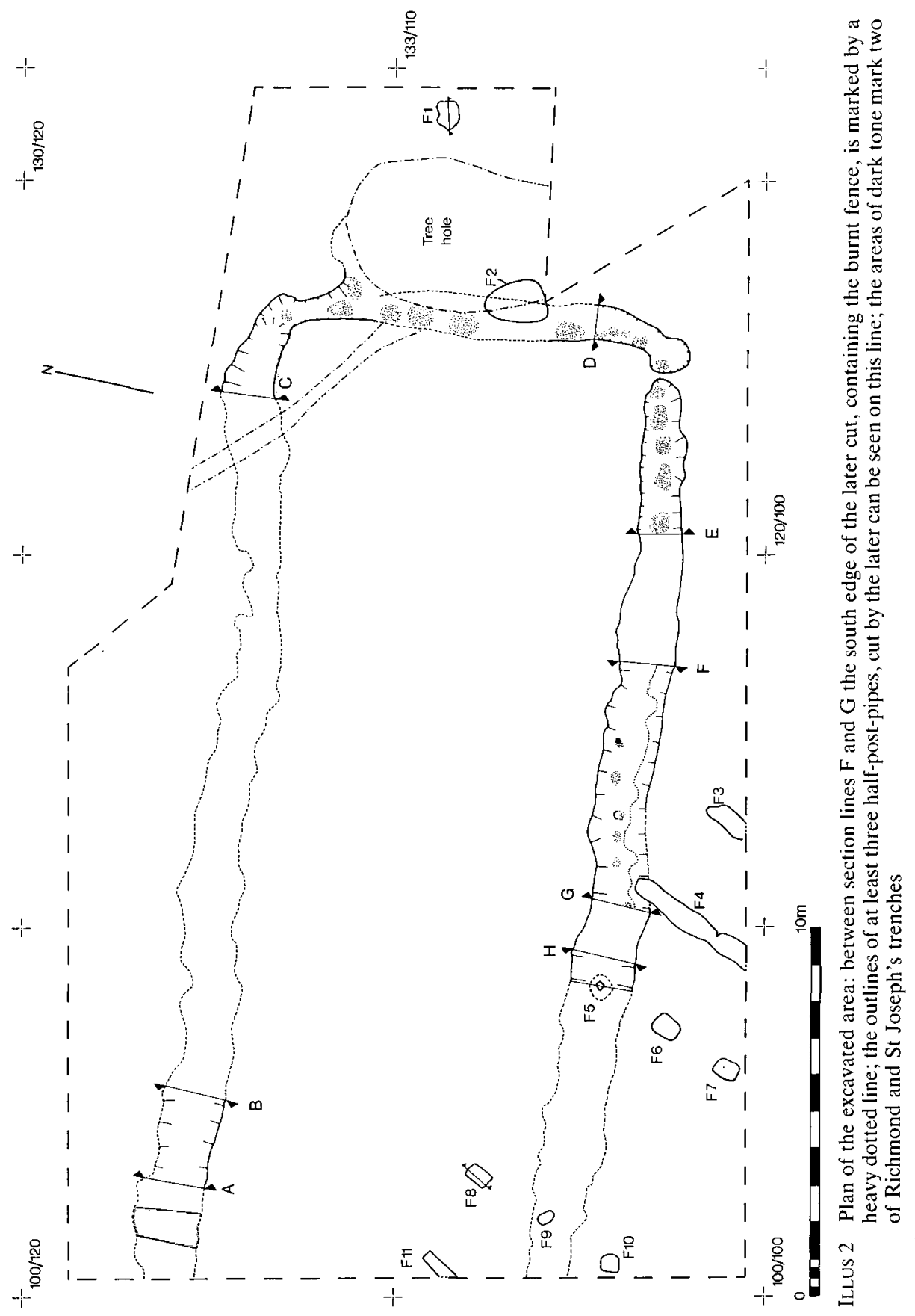




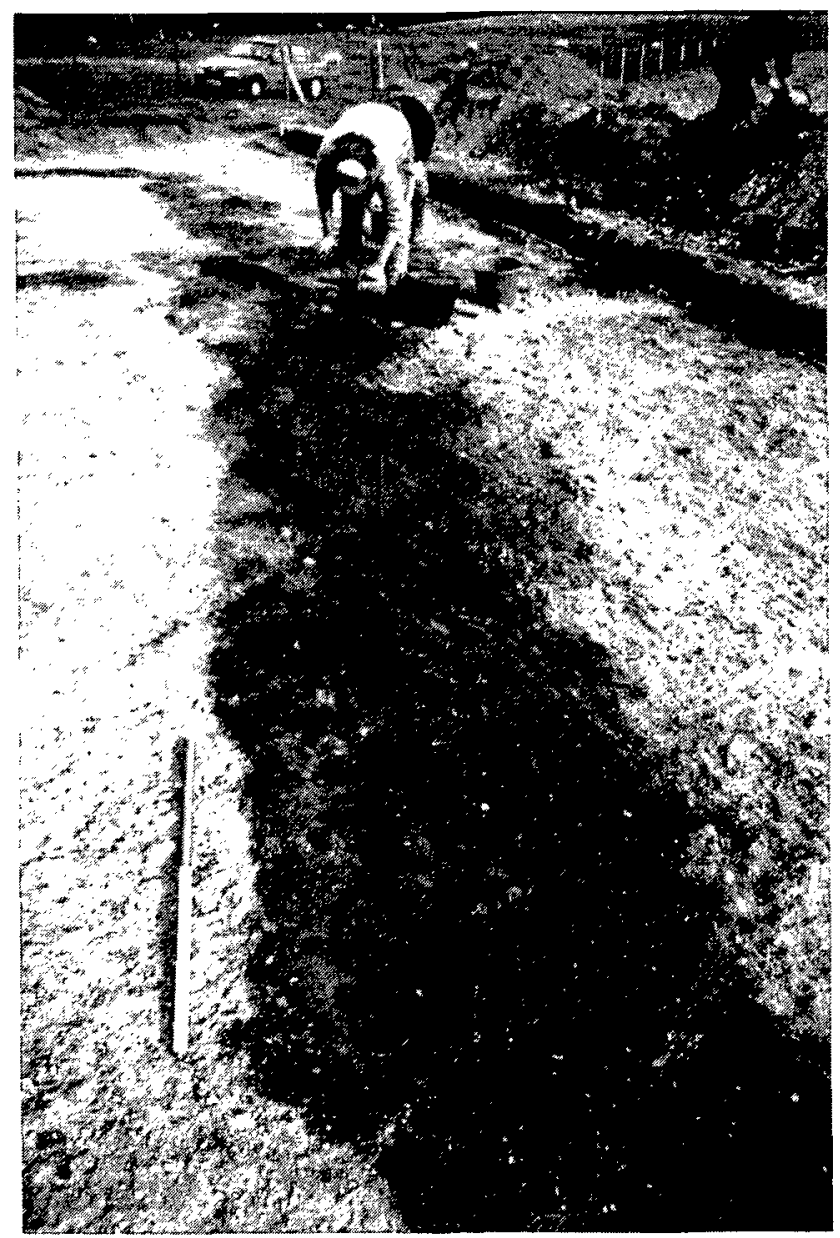

ILlus 3 Surface of the south ditch, looking east, during cleaning; the black and orange layers, resulting from the burning, are visible on the left side of the ditch, even in monochrome

The ditch at the east end was difficult to trace because it had been severely affected by disturbance of a different kind: a Roman pit (F2) had been dug through part of it and subsequently an even greater portion of it had been disturbed by the growth of what must have been a very large tree, probably one of an avenue indicated on an early plan of the estate. The extent of the tree-root disturbance is marked on illus 2 .

A further contrast between the north and south ditches was provided by the amount of burnt material visible on the cleaned surface of the southern ditch (illus 3 ). As excavation proceeded, it became clear that, while this difference was in part due to the greater depth to which the southern ditch had been eroded, it was in the main a reflection of the relative amounts of burnt material present.

The surface of the ditch was cleaned throughout the area under inspection, and portions were selected for excavation. They were the whole east end, two long sections of the south ditch (only parts were bottomed), the eastern end of the north ditch, and a narrow section near the west end of the north ditch. In all sections, but more particularly in the longer ones, 


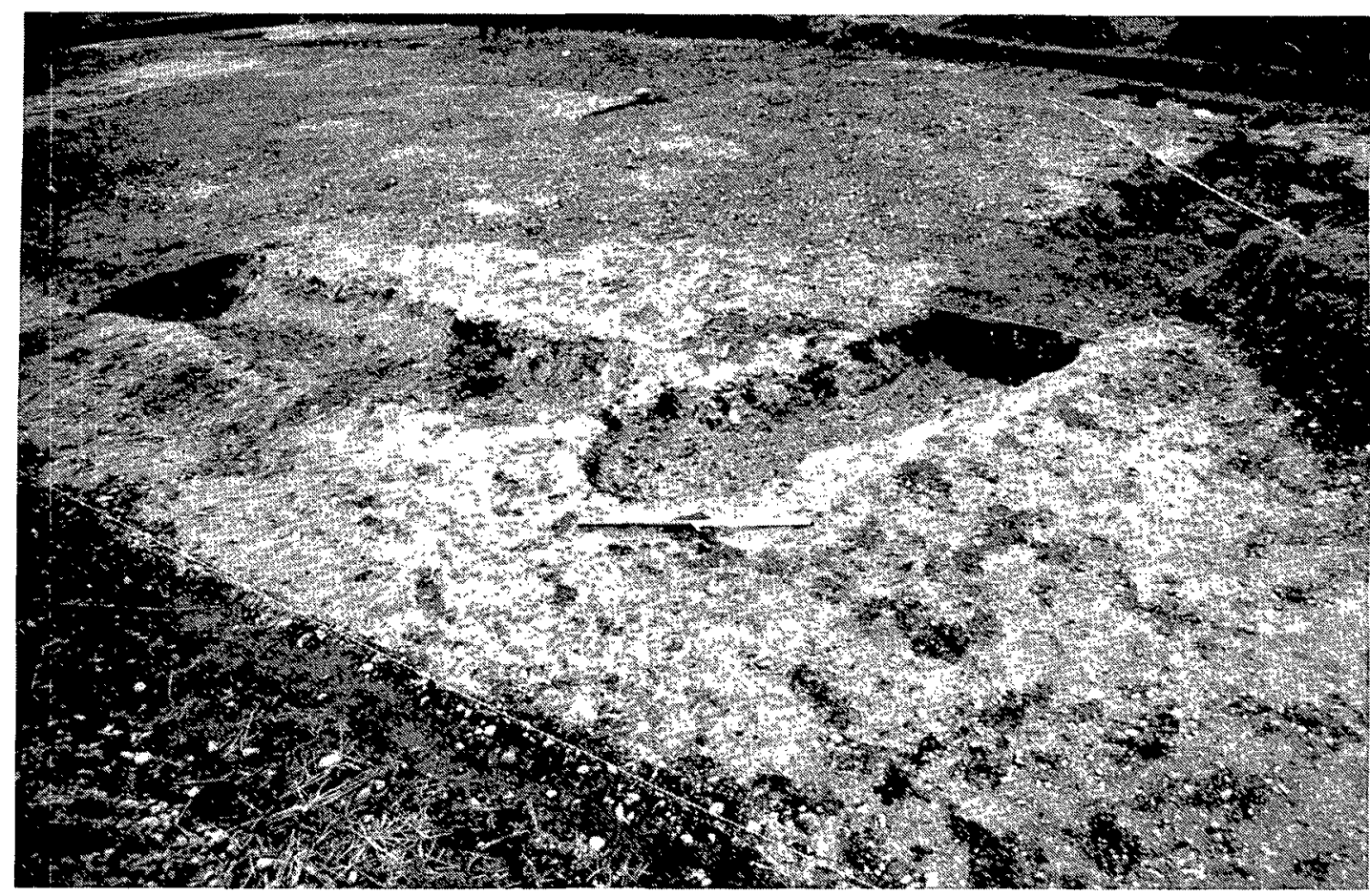

ILLUS 4 South-east corner of the enclosure, after excavation

excavation proceeded in shallow spits, each level being planned before it was taken down. In general, the ditch-fills on the northern side provided little information in plan. The east end, although disturbed, revealed evidence for a line of at least 12 posts, each marked by a roughly circular concentration of charcoal flecking. The eastern edge of the ditch at the east end had been particularly badly damaged by tree root action. However, at one point immediately to the north-west of the tree-hole, the outer edge of the ditch turned to the east, suggesting that the ditch may have broadened or bifurcated at this point.

The ditch on the southern side survived only to a limited depth, particularly at the south-east corner, but it contained evidence of a complex sequence of events. The most prominent soils in the ditch were the orange/red soils and the charcoal concentrations. The sequence can be best understood by reference to the cross-sections.

Eight cross-sections across the ditch are illustrated (illus 9). The ditch, irregular in plan, was $1.1-1.7 \mathrm{~m}$ across and a maximum of $0.6 \mathrm{~m}$ deep below the subsoil surface. One clearly defined causeway (only $0.14 \mathrm{~m}$ across) was located at the south-east corner. The ditch appeared to be made up of segments, most of which were interlinked (the south-east causeway might not have reached the original ground surface, so narrow is it). Discontinuities can be seen in the line of the ditch about $2 \mathrm{~m}$ to the east of section $\mathrm{G}$, about $3 \mathrm{~m}$ to the east of section $\mathrm{B}$, and at the north-east and south-east corners (illus 4). Clear discontinuities can also be seen in the unexcavated west part of the enclosure, both on the aerial photographs (illus $5 \& 6$ ) and the plot of the cropmarks (illus 7). The ditch seemed throughout its exposed length to be a strictly unilinear feature, with the exception of one point at the east end. Immediately to the north-west of the area severely damaged by the tree-hole, the outer edge of the ditch seemed 


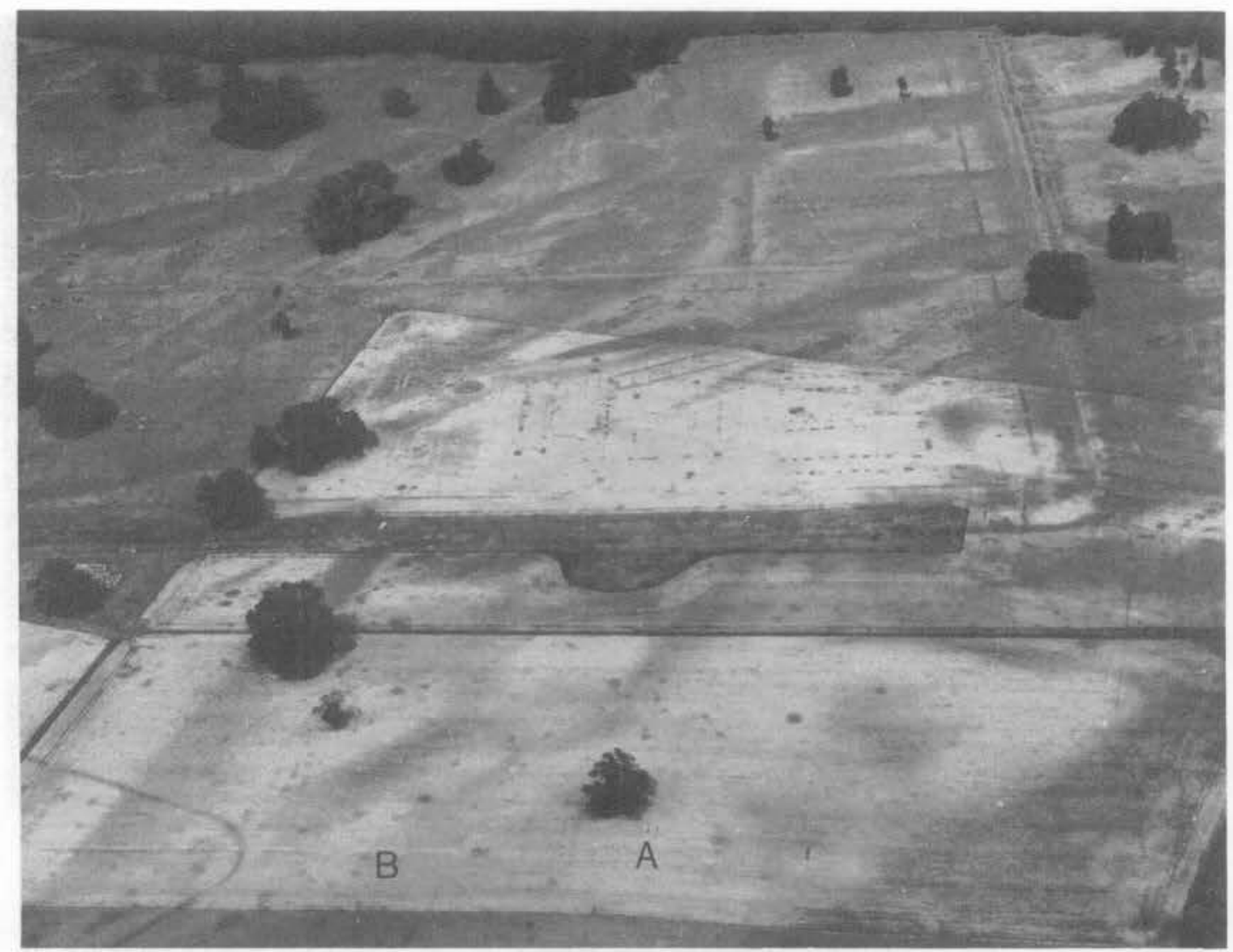

ILLus 5 Aerial view of Inchtuthil from the south-south-west, taken in 1984 by Dr Colin Martin (Scottish History Collection, University of St Andrews). The Neolithic enclosure lies in the centre; in the centre foreground immediately to the left of point ' $\mathrm{A}$ ' is a circle of 13 pits appearing as cropmarks; a second possible pit circle, of a different character, lies immediately to the left of point B

not to parallel the inner ditch edge; instead it turned to the east, in the direction of a well-preserved post-pipe lying off the main fence line. Unfortunately the disturbance caused by the tree-hole prevented any further analyis of the stratigraphy. It is possible, particularly given the presence of a post at this point, that there was some elaboration of the east end of the enclosure, in the form of an additional post-setting. Possible parallels are considered below.

Ditch sections B, F, G and $\mathrm{H}$ show most clearly the relationship of the burnt material to the other fills. In section $\mathrm{H}$ a band of heavily charcoal-impregnated loam is overlain by a band of bright orange gravel, and the other sections, as well as the areas taken down in plan, duplicated or reflected this. The charcoal layer was continuous and relatively undisturbed. In the area between sections F and G six contemporary post-pipes were located, some still containing evidence of a burnt post. In particular, two post-pipes preserved, on the sides facing the interior of the enclosure (illus 8), clear traces of the charring of the timber; modern observations show that in a relatively short-lived fire major pieces of timber will char quickly, leaving the inner part of the post untouched for some time; this is what may be indicated here.

The bright orange colour of the layer above, below, or sandwiching the charcoal does not occur naturally on site, and it is suggested that it results from the effect of fire on the soils in an oxidizing atmosphere. 


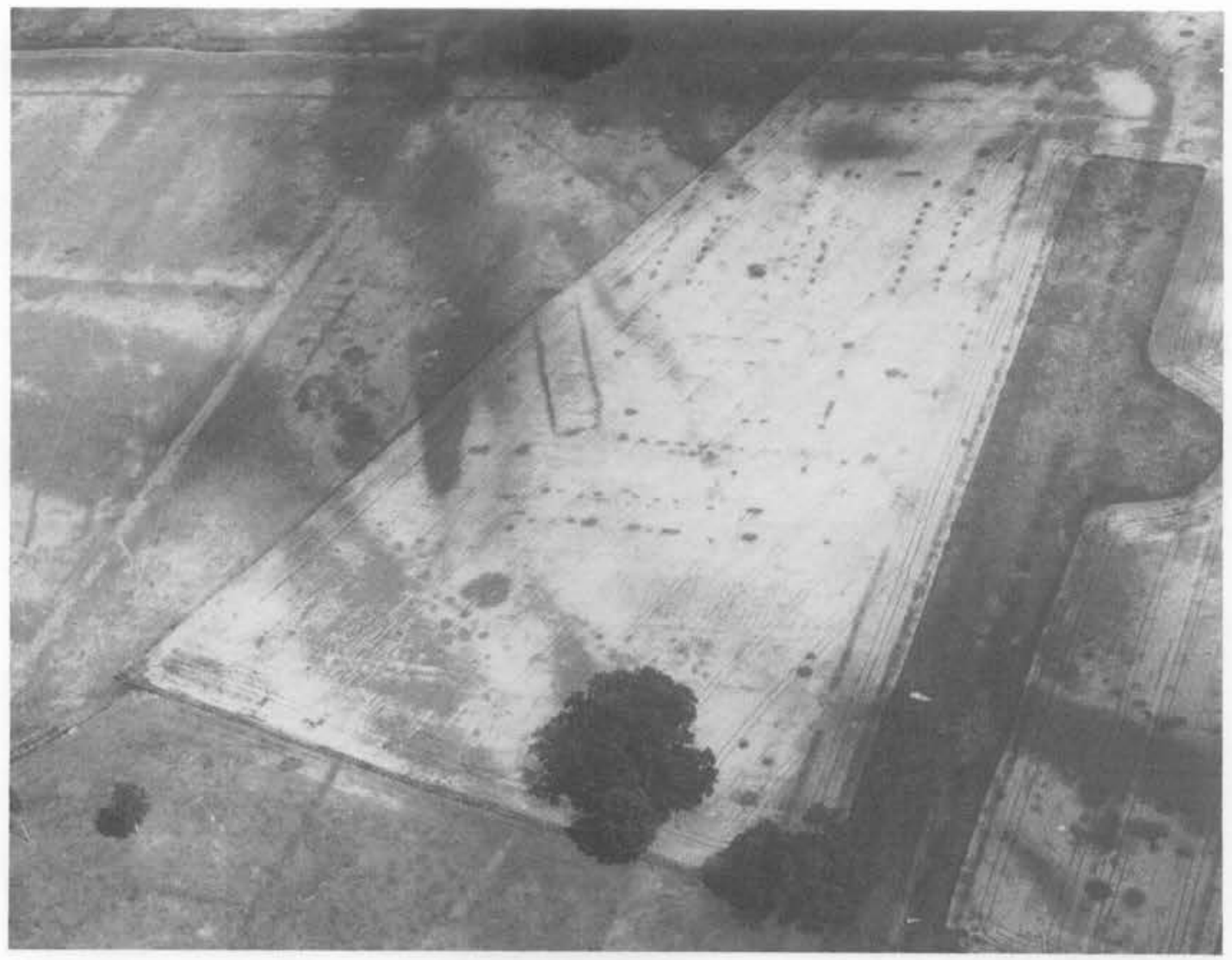

ILLus 6 Aerial view of the enclosure, seen from west, taken in 1984 by Dr Colin Martin (Scottish History Collection, University of St Andrews). The kink in south (right hand) ditch near its west end is very pronounced

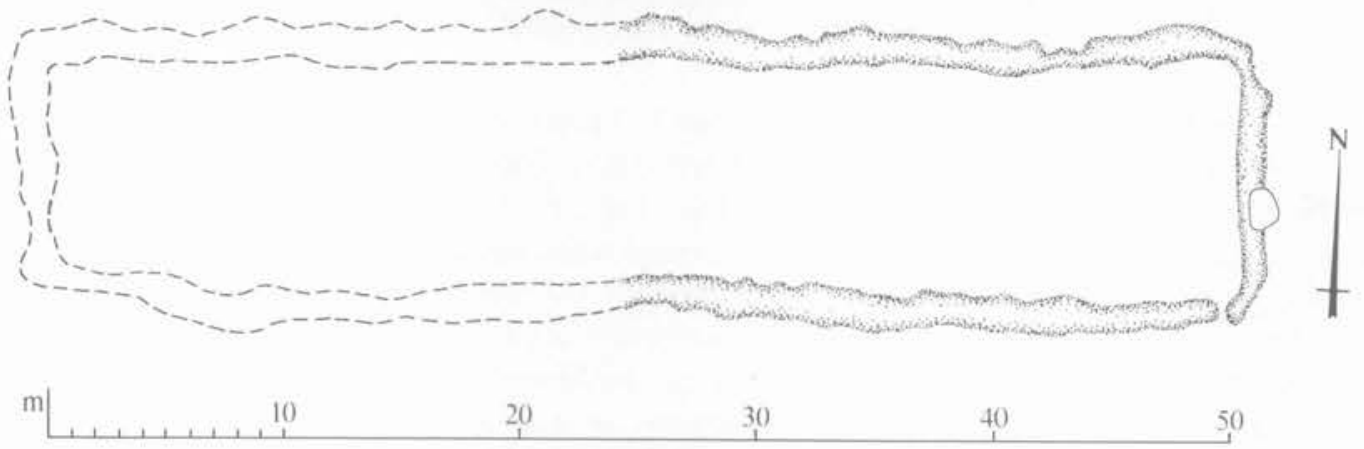

ILLus 7 Plan of the long mortuary enclosure, prepared by RCAHMS combining the excavation information (for east half) and a new plot of the cropmarks (for west half). (RCAHMS, Crown copyright)

The upright posts, the charcoal layer and the layer of apparently fire-reddened soils are interpreted as the remains of a wooden fence. The fence would have been supported on substantial oak posts linked by timbers of mature oak (see Mills below), giving rise on burning to the continuous heavily charcoal-impregnated layer. The consistent angle at which the charcoal layer rests suggests that the fence fell or was pushed towards the interior of the 


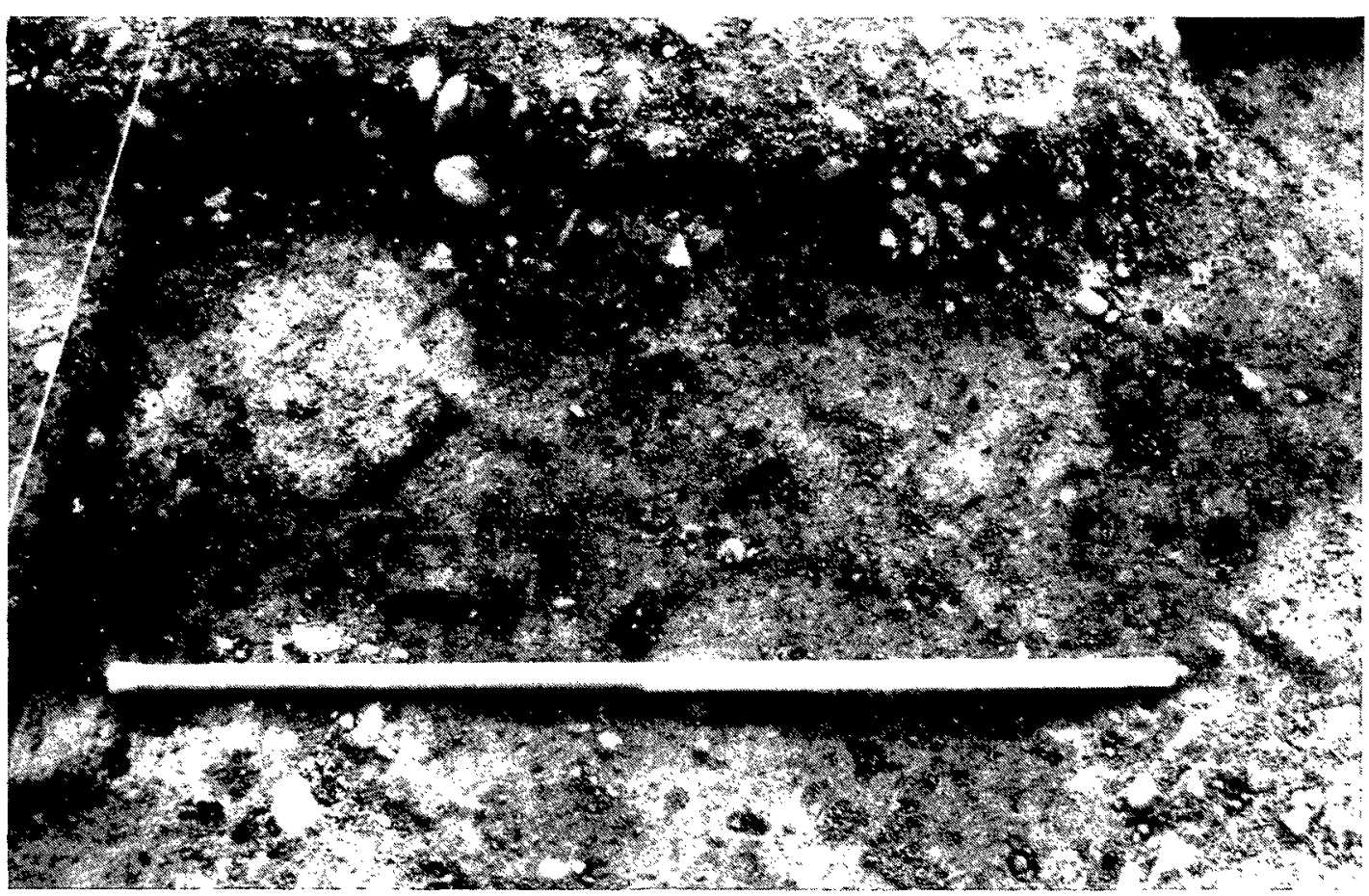

ILLUS 8 Photograph showing charring on the inner (north) side of post-pipes in the area of ditch between section lines $\mathrm{F}$ and $\mathrm{G}$

enclosure and that the ditch was not fully filled. The fire-reddening of the soils over and to a lesser extent under the charcoal suggests, too, that the structure was still burning when it fell and that in most places soil was thrown over the still burning remains. The layers of charcoal and fire-reddened soil are too consistent to allow for any interpretation involving the redeposition of burnt material from elsewhere, and the survival of post-pipes showing the effects of burning supports the interpretation of the fence having been set up in the ditch.

Two charcoal samples, of oak from the burnt fence, were submitted for radiocarbon dating. The results were:

sample 5A (GU-2760) 3210 770 bc

sample 6A (GU-2761) 3120 50 bc

It became clear, as excavation proceeded, that the more loamy soils associated with the erection and destruction of the wooden structure occupied a cut made through a layer of compacted gravel very similar to the natural subsoil, up against the outer side of the ditch. This shows particularly clearly on sections F (right-hand-outer-side) and G (left-hand-outer-side) in illus 9 . In plan, the outer edges of three post-pipes were clearly visible in this layer against the outer side (illus 2). This is interpreted as the remains of a first phase of fence-building in the ditch; after this phase of the use of the ditch, when the remains of this postulated first fence had rotted or been removed, it is suggested that the ditch was recut, but not to the full depth or width of the original cut, and the second fence, subsequently burned down, was erected. There were hints in a number of areas of a final phase of disturbance, perhaps associated with yet another episode of fence-building, but the evidence was inconclusive. Within the enclosure 

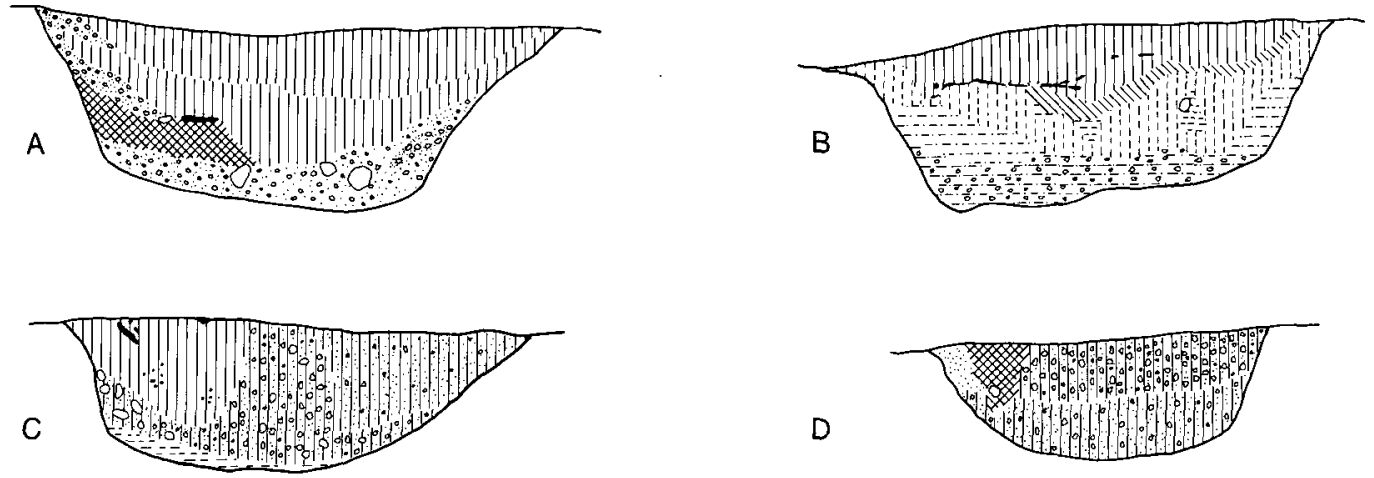

$E$
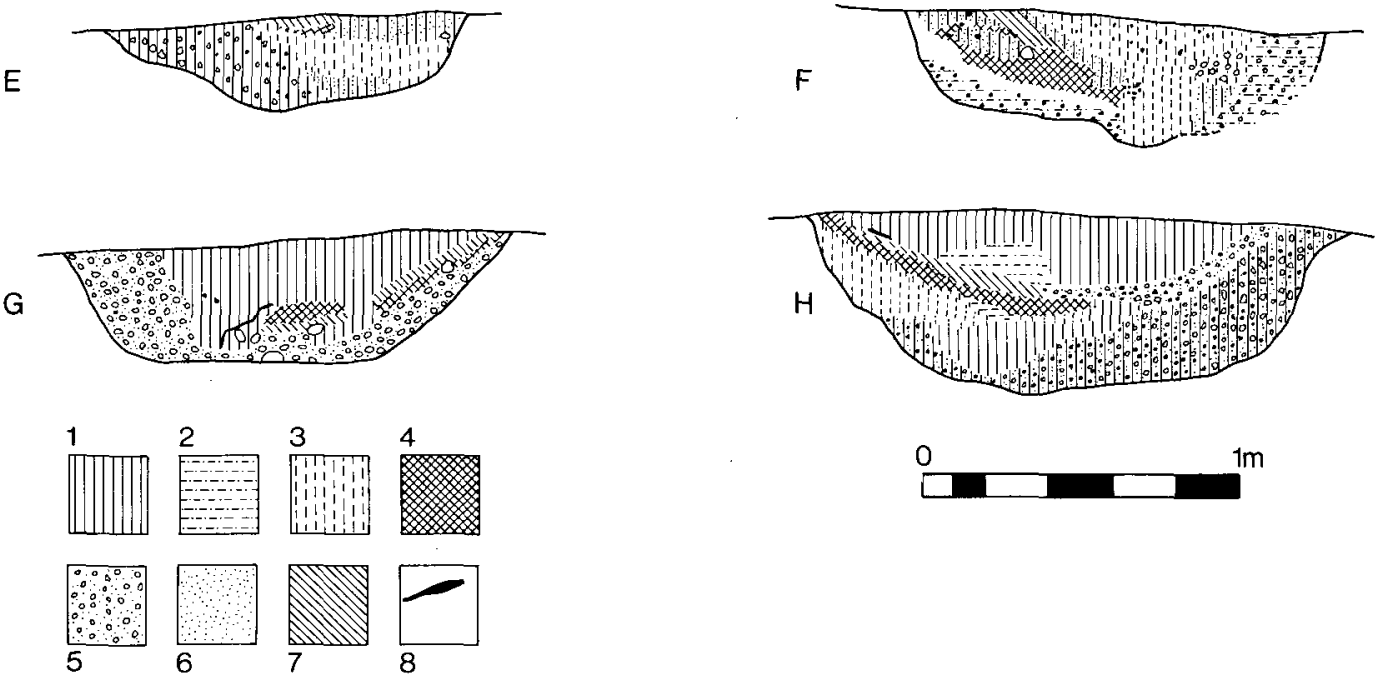

ILLuS 9 Ditch sections. Key: symbols may be combined. 1, loam; 2, silty sand/sandy silt; 3, silty loam/loamy sand; 4 , charcoal staining; 5 , sandy gravel; 6 , sand; 7 , burnt orange gravel or sandy silt; 8 , solid charcoal

$\mathrm{F} 1$
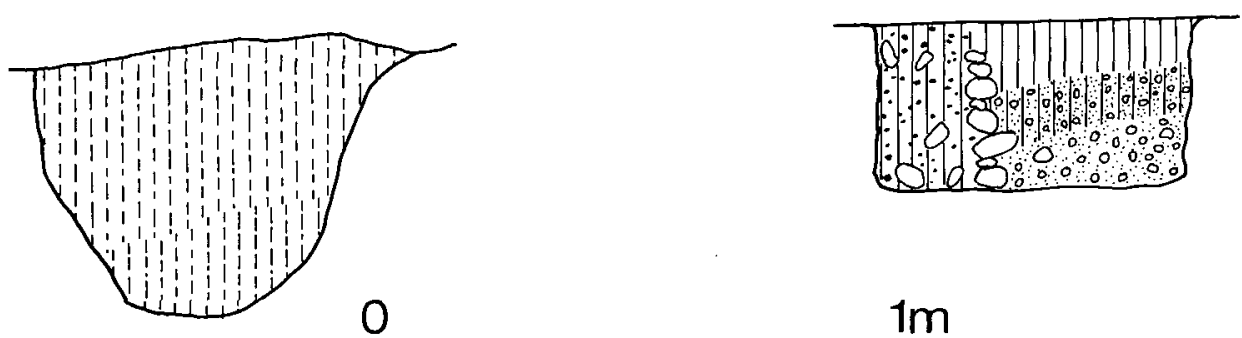

F8

$1 \mathrm{~m}$

ILLUS 10 Miscellaneous sections: F1, pit, probably prehistoric; F8, post-pit of barrack block 6 
patches of a hard, greasy, grey-brown layer survived, clearly in the process of being ploughed away by modern agriculture. More extensive remains of a relict B horizon survived, particularly on the north side, both inside and outside the enclosure, masking the north ditch to some extent. It may be that these fragments reflect the survival until recently of a buried land surface contemporary with one of the earlier uses of the area.

\section{OTHER PREHISTORIC FEATURES}

Only one other feature of probable prehistoric date was recovered (F1; illus 10): a pit measuring $0.65 \mathrm{~m}$ in diameter and $0.55 \mathrm{~m}$ deep. The pit had two fills: the upper a medium-brown fine silt loam, the lower a dark brown fine silt loam. The interpretation of the pit is not clear; it may have been a post-hole, although no post-pipe was visible.

\section{THE BURNT TIMBERS}

Coralie Mills

\section{METHODS}

Short lengths of burnt timbers were selectively sampled in the field, and 11 samples were forwarded for analysis. The samples were wrapped in aluminium foil to hold them together. Where timbers were sufficiently well preserved, their dimensions and cross-sections were recorded. Identification followed the keys in Schweingruber (1978).

\section{RESULTS}

All 11 samples are of oak (Quercus spp.), and the timbers were cut from mature, slow-grown trees. There is no young roundwood timber present in the selected assemblage. The timbers have not survived well, showing varying degrees of fragmentation and infiltration by mineral matter and by fine roots. The surfaces of the samples are rather eroded, so that no woodworking marks can be observed. Details of the form of each timber are given in the version of this report lodged in the NMRS. In the better-preserved samples, it is clear that the timbers have been radially split.

\section{DISCUSSION}

Analysis of the samples from the burnt structure at Inchtuthil suggests that it was constructed of radially split oak timbers (in contrast to the tangentially split timbers at Haddenham (Morgan 1990)). The timbers originated from mature, slow-grown trees, at least one of which is likely to have been in excess of 190 years old when felled. The form of the timbers is variable, with samples 5 and 6 being of narrow planks while 7 represents a stake and 12 is possibly part of a post. There is no evidence of a wattled structure amongst the examined assemblage.

The excavators have interpreted the site as a Neolithic mortuary enclosure. Oak timbers have been used in the construction of several Neolithic mortuary structures. In Scotland, for example, evidence of a timber mortuary structure and façade was found under the long cairn at Lochill, Kirkcudbrightshire, and remains of a burnt oak plank floor were found within the mortuary structure (Masters 1973, 97). The identifiable charcoal from the Dalladies long barrow (Grampian) was of oak (Piggott 1972). However, it is not clear whether this charcoal represents the remains of structural timbers. 
There are several long barrow sites where there is evidence of a trapezoidal timber enclosure forming an early part of the sequence of construction, and in several instances burnt oak timbers have been identified. These sites are discussed in more detail by the excavators below.

Oak is easily split, and is strong and durable (Taylor 1981, 53), making it an ideal timber for many types of construction. Therefore, the employment of oak timbers in many Neolithic mortuary structures is perhaps not surprising. However, what remains unknown is whether timber selection was based entirely on practicalities of construction, or whether other, possibly cultural, factors were in operation.

\section{THE PREHISTORIC FEATURES: DISCUSSION}

The excavations reported here showed that the ditch had been dug in irregular segments, generally linked, and consequently varied appreciably in line and dimensions. It had been used as the bedding trench for what appeared to have been a wooden fence supported by substantial posts set at 1.6-2.4 m intervals, packed into position with clean gravel. The post settings of this fence survived as semicircular areas of loamy soil outlined on the southern side by the clean gravel at the outer edge of the ditch in the segment excavated between sections $\mathrm{F}$ and $\mathrm{G}$. The northern half of the post-pipes, and the remainder of the fills associated with this use, seemed to have been removed or disrupted by the digging of a bedding trench for a second fence.

The second fence had been set on fire and, apparently while still burning, had fallen, or been pushed over, towards the interior of the enclosure. The continuous charcoal band thus produced (particularly on the south side) indicated that the upright posts had been linked to form a continuous barrier. The gravel and sand immediately overlying the charcoal was in most places burnt bright red/orange, indicating that it had been deposited while the wood was still burning. The charcoal and red/orange layers were extensive, consistently present, clearly defined and not redeposited. The burnt material had been dug through at a later stage. No contemporary artefacts were found. The traces of this fence were best preserved on the south side, where it was clear that the spacing of uprights was, very roughly, $0.8 \mathrm{~m}$. On the north side, the burning seemed not to have been so intense, and the amount of animal disturbance greater, resulting in less coherent stratigraphy. The posts on the east end were spaced probably at similar intervals.

As discussed above, the growth of a large tree had disrupted the east end considerably, but slight indications of more elaborate structure in this area could be identified. It may be that the ditch bifurcated near the north-east angle, providing the bedding for a line of posts aligned at right angles to the east end. A similar feature may have been provided near the south terminal of the east end, thus forming a shallow post-defined forecourt, but all evidence of this was removed by the intrusive Roman pit and tree-hole.

The possible survival of what seemed to be a relict topsoil mostly within the eastern end of the enclosure, but fading into the relict soil partly obscuring the northern ditch, must be considered. The authors would hesitate to identify the layers as remains of a land surface contemporary with the enclosure. To have survived on the exposed gravel ridge, still under active cultivation, we would have to postulate that this surface was buried under at least $0.25 \mathrm{~m}$ of soil which had been deliberately deposited. There are three periods in which such soil movements could have been made: the early modern period, the Roman period, or the period of the construction of the enclosure itself. We might, for example, speculate as to whether the enclosure, in its final phase, was mounded over, to form a long barrow. 
Even before the excavation reported here, it seemed very likely that the parallels for the enclosure or for elements in its structure lay firmly in the Neolithic period. The linked-segment style of digging ditches, where the alignment of individual segments can vary somewhat, seems to be a characteristic of Neolithic construction. It is interesting to note that the same technique is visible in the cropmark sections of the Cleaven Dyke, a probable cursus monument situated $3.5 \mathrm{~km}$ to the east.

In the most comprehensive survey of ditched enclosures of this type, Loveday \& Petchey (1982) identified three morphological sub-types: oblong, ovate and trapeziform. The Inchtuthil enclosure is trapeziform, but not so pronouncedly as was suggested in the diagrammatic representation first published (Pitts \& St Joseph 1985, fig 75). Loveday \& Petchey point out the dangers of classification by simple morphological analysis, which can assume that small variations in basic shape were necessarily significant to the builders. In this context the south-west corner of the Inchtuthil enclosure is of interest; why does the ditch change course so radically about $8 \mathrm{~m}$ to the east of the corner?

Two northern English examples, Kilham and Skendleby - at one stage in their development into long barrows - take the form of trapezoidal palisaded enclosures (Phillips 1935; Manby 1976). The parallel between the size and nature of the enclosures at Kilham and Inchtuthil is particularly striking, notably in the irregular plan of the ditch. The radiocarbon date for Kilham is $2880 \pm 125 \mathrm{bc}$, compared with the Inchtuthil dates, for old oak, of $3210 \pm 70$ and $3120 \pm 50$ bc. The palisaded enclosure phase of the monument at Fussell's Lodge also closely parallels the Inchtuthil enclosure (Ashbee 1966). The only radiocarbon date from this site, albeit of oak from the mortuary structure, is $3230 \pm 150$ bc (BM-134). These sites were all completed as long barrows; at other morphologically similar sites this stage of use either cannot be identified or was apparently not felt necessary by the communities building and using them. There are similarities in the construction of the forecourt enclosure at Nutbane (Morgan 1959).

The local parallels for Inchtuthil are not close. At Douglasmuir, Kendrick (1980) excavated a post-defined enclosure measuring $65 \times 19 \mathrm{~m}$ and internally divided, from which one radiocarbon date, of $2900 \pm 55$ bc (GU-1210), was derived. At Balfarg, two post-defined enclosures surrounding the remains of free-standing post settings were dated to the mid-third millennium bc; they were associated at the end of their use with Grooved Ware and may have been mounded over (Barclay 1984; Barclay \& Russell-White forthcoming). The only long barrow excavated in Scotland, at Dalladies (Piggott 1972), had no detectable phase as a post-defined enclosure. The interpretation of the timber structure below the mound at Court Hill, Dalry, as a Neolithic mortuary building (Coles \& Simpson 1965; Linge 1987), has recently been challenged (Scott 1989).

The dimensions of some trapezoidal enclosures, whether defined only by posts or by posts set in a trench, are summarized in the table.

TABLE 1

Dimensions of the Inchtuthil enclosure and possibly comparable structures

\begin{tabular}{|c|c|c|c|}
\hline \multirow[t]{2}{*}{ Site } & \multirow[t]{2}{*}{ Length ( $\mathrm{m})$} & \multicolumn{2}{|c|}{ Width (m) } \\
\hline & & $\operatorname{Max}$ & Min \\
\hline Inchtuthil & 50 & 10.1 & 8.4 \\
\hline Kilham & 58 & 10.7 & 8.5 \\
\hline Fussell's Lodge & 41.1 & 12.2 & 6.1 \\
\hline Rivenhall & 49 & 16 & \\
\hline Dalry & 14 & 6 & \\
\hline Dorchester VIII & 57.9 & 18.3 & \\
\hline Wor Barrow & 45.7 & 24.4 & \\
\hline
\end{tabular}


Loveday (1985) has argued that the enclosures which were not mounded over ('long mortuary enclosures') are the lower end of a continuum of sites which include, at the other extreme of size, the major cursus monuments. The enclosures form a distinct group $20-80 \mathrm{~m}$ in length, with a few up to $140 \mathrm{~m}$. The next major grouping ('minor cursuses') are $200-500 \mathrm{~m}$ in length and are considerably wider than the normal 15-20 m of the oblong ditches. He notes the association of ring ditches and cursuses with oblong ditched enclosures. In this context the presence of a pit circle to the SSW of the Inchtuthil enclosure (illus 5) is of interest; these sites may be of ceremonial or funerary function (Tolan 1988), and the Cleaven Dyke has been reinterpreted as a cursus (Pitts \& St Joseph 1985). Recent RCAHMS aerial survey in the Blairgowrie area has revealed the presence of what appears to be a pit-defined cursus at Haugh and the possible remains of a Balfarg-type timber structure at Littleour, just to the north of the Cleaven Dyke. Mention must also be made of the probable cursus adjacent to a barrow cemetery at Blairhall on the left bank of the Tay some $11 \mathrm{~km}$ to the south of Inchtuthil.

A large sherd of earlier Neolithic pottery was found on the Inchtuthil plateau in the excavations at the beginning of this century; a note on the sherd is being prepared for publication by Trevor Cowie.

There are few securely contexted radiocarbon dates for earlier Neolithic activity in Tayside (eg Dalladies 3240 105 bc (I-6113); 2710 \pm 50 bc (SRR-289); 2585 \pm 55 bc (SRR-290) (Piggott 1972, 44); Pitnacree 2860 90 bc (GaK-601) (Coles \& Simpson 1965, 46); Douglasmuir 2900 55 bc (GU-1210) (Kendrick 1980); North Mains ring ditches $2690 \pm 65$ bc (GU-1546) (Barclay 1983, 259)). Although there is evidence for cereal cultivation in a similar riverside situation, at around $3730 \pm 70$ bc (GU-1725) at North Mains in Strathearn, only some $30 \mathrm{~km}$ distant (Hulme \& Shirriffs 1985), it may be suggested that the dates clustering around $3000 \mathrm{bc}$ might represent the earliest substantial phase of agricultural clearance and settlement of much of the Tay/Earn catchment area, marking an expansion from more limited earlier clearance for farming. These late fourth/early third millennium dates are paralleled at Balbridie to the north in Grampian Region and in the earliest detected phase at Balfarg, to the south, in Fife. The Tay/Earn catchment area, through the effect of aerial reconnaissance, is becoming increasingly densely scattered with monuments of possible Neolithic date and seems to offer an increasingly good opportunity for the study of the development of Neolithic and early Bronze Age settlement. The excavations of the settlement enclosures at Kinloch, Fife (Barber 1982), and at North Mains (Barclay \& Tolan 1990) show that activity of this period may not be represented solely by surviving monuments of funerary/ceremonial sites, although in neither case is the dating of the double enclosure ditches as secure as could be wished.

\section{ROMAN STRUCTURES AND ARTEFACTS}

Although the primary objective of the 1989 excavation at Inchtuthil was the examination of the ditched enclosure, due attention was also paid to those structures and features of Roman date which fell within the area stripped. Foremost among these were the northern extremities of barracks 5 and 6 , the easternmost members of the block of six barrack-buildings situated in the praetentura of the fortress, immediately east of the via praetoria. Portions of barracks 3, 4 and 5 had already been examined by Richmond and St Joseph, who demonstrated beyond doubt that the post-pits and post-trenches of the Roman buildings had been cut into the already-filled ditch of the enclosure - a sequence confirmed in 1989. 
The additional information about Roman Inchtuthil which is presented in this report is relatively slight: the line of posts supporting the north end of the verandah of barrack 5 was identified, together with a part of the verandah of the opposing barrack (no 6), as well as the post-trenches defining its range of external rooms (illus 11). The form and dimensions of the structural remains conformed with those established by cross-trenching in the southern portions of the same blocks between 1952 and 1960 (Pitts \& St Joseph 1985, 176 and fig 81): the street separating the two buildings was about 20 Roman $\mathrm{ft}(6 \mathrm{~m})$ wide, the verandahs each $10 \mathrm{ft}$ in width and the outer range of rooms in barrack 6 also about $10 \mathrm{ft}$ in width. As in barracks elsewhere in the fortress, there was no post-trench to mark the end of the building, and the longitudinal trench provided for the internal division stopped some way short of the position of that end-wall. Furthermore, and perhaps more significantly, there was no trace of either internal cross-divisions between contubernia or drip-trenches to catch the rain shed from the sloping verandah-roofs on each side of the barrack-street; it is possible that these elements, being shallower than the others, had been removed by ploughing, which would have had a more powerfully erosive effect in this area, ie on the crest of the ridge along which the enclosure was aligned.

The only feature to be sectioned and examined in detail was the northernmost post-pit of the barrack 5 verandah, although surface indications of the corresponding pit in barrack 6 suggested an identical arrangement. The former was rectangular on plan, measuring about 0.6 $\times 0.4 \mathrm{~m}$ and cut $0.32 \mathrm{~m}$ into the subsoil. The impression of a timber upright, measuring approximately $0.17 \times 0.19 \mathrm{~m}$ in cross-section and probably withdrawn during the demolition of the fortress, could easily be distinguished in its south-west angle; the fill of the pit itself (illus

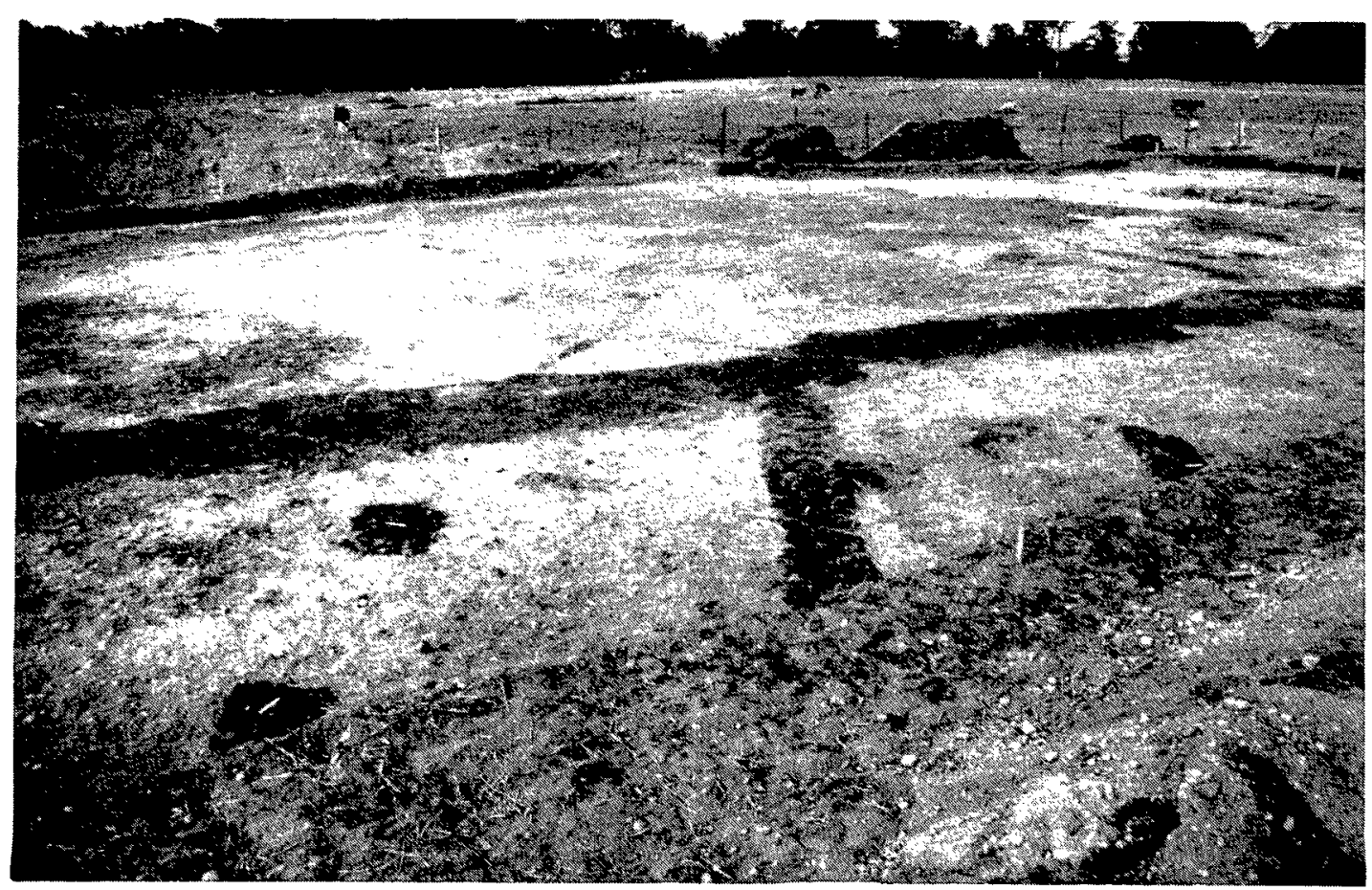

ILLUS 11 Elements of barrack 6 
10) was clearly stratified in the order of its original digging, which suggests careful backfilling of the upcast material in the construction-phase.

That equal care was taken with the dismantling of the fortress installations on its evacuation in C AD 87 was amply demonstrated by the 1952-65 excavations (Pitts \& St Joseph 1985 , passim). Even within the relatively small area uncovered in 1989 , further evidence of deliberate demolition was forthcoming, in addition to the indication of uprooted verandahposts. For example, the recovery from unstratified debris-layers of iron nails with their shanks bent, as if by extraction with a claw-hammer, provided supportive, if undramatic, testimony to the nature of the abandonment.

From the disturbed area to the north-east of the enclosure, however, there was more explicit evidence. Although the presence of the tree-hole referred to above had greatly obscured the situation, it would appear that Roman demolition-teams had dug a rubbish pit and subsequently filled it; the upper fill consisted of turfy loam flecked with charcoal and calcined bone. A well-preserved iron axe-head was recovered from very near the top of this pit (see below). As far as could be ascertained, the axe-head was in excellent condition when deposited, and its loss may have been accidental. Possibly the tool was laid on one side during a rest from work and then covered mistakenly with debris; alternatively, the head may have flown off or the haft may have snapped under the pressure of work. In either case, it is easy to imagine the axe being wielded to good effect by a legionary demolition-team in the last hours of the Roman occupation!

\section{ARTEFACTS}

\section{Pottery}

The majority of Roman artefacts found during the 1989 excavation were severely abraded coarse-ware sherds, probably from bowls, jars and lagenae, and mostly in buff or pinkish sandy fabrics. Apart from the fragment of an amphora-neck, of uncertain type, found on the surface of the excavated post-pit, none could be associated with any of the identified structures.

\section{Metal}

Fragments of three iron nails, all with bent shanks, were found in unstratified contexts, along with the pottery, in the lowest levels of the modern ploughsoil.

The iron axe-head, which was found in the uppermost fill of the presumed Roman demolition-pit (illus 12), is a notably fine example of the standard single-bladed axe of legionary pattern. It measures $282 \mathrm{~mm}$ in length, and its width tapers evenly from $56 \mathrm{~mm}$ at the squared butt to $8 \mathrm{~mm}$ at a distance of $25 \mathrm{~mm}$ from the blade-edge. The slightly curved blade is $130 \mathrm{~mm}$ long and the slip-eye, near the butt, is provided with side-clips which project from the upper and lower surfaces. It is beautifully crafted in a solid piece and it is in every way comparable with the legionary felling-axe (also of late-1st-century date) discovered in Pit XVI at Newstead (Curle 1911, 282-3 (where its length is incorrectly given as 40 inches) and plate Ixi, 4). Only when its conservation is complete will it be possible to determine if, like that specimen, it bears a maker's stamp and owner's mark. A less perfect example was found, also in a Flavian context, at the fort of Strageath (Frere \& Wilkes 1989, 160-1; for analogies cf Manning 1966, 11-13). 


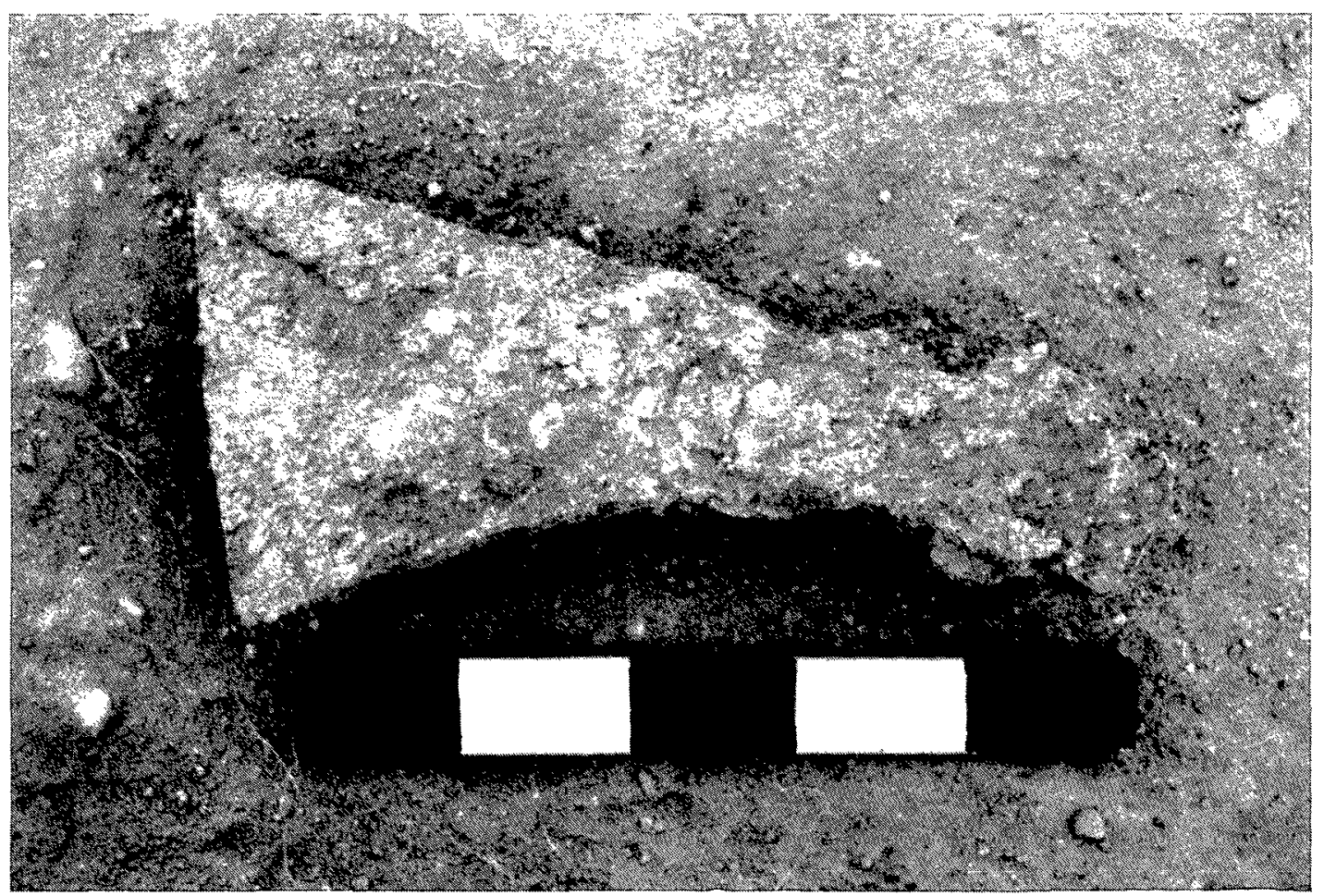

ILlus 12 Axe: scale is $25 \mathrm{~cm}$, in $5 \mathrm{~cm}$ units

\section{ACKNOWLEDGEMENTS}

We are most grateful to the Society of Antiquaries of London, the Society of Antiquaries of Scotland and the Prehistoric Society for providing the funds necessary for the fieldwork and post-excavation analyses, and to Historic Scotland for providing the radiocarbon dates through their arrangement with SURRC. Survey and excavation equipment was kindly made available by the Department of Archaeology of the University of Edinburgh and by Historic Scotland.

We are grateful to Colonel G Dunphie, chairman of the trustees of the estate, and to $\mathrm{Mr}$ David Gemmell, their tenant, for permission to excavate. Our thanks also to $\mathrm{Mr}$ and $\mathrm{Mrs}$ Taylor of Garden Cottage for their help. The area of the fortress is a scheduled ancient monument; we are grateful for the consent of the Secretary of State for Scotland to undertake work on the site.

Myra Tolan acted as assistant director; we would like to express our great thanks to her and to Jim Inglis, Ralph Troup, Philip Nappi and Gil Reid for all their hard work on site, and to Catrina Appleby and Stephen Fulford for their days on site.

We are grateful to Dr Colin Martin for permission to reproduce illustrations 5 and 6 , which are from the Scottish History Collection, University of St Andrews; to RCAHMS for permission to reproduce illustration 7, which is from the forthcoming South-East Perth volume; and to the Historic Scotland photographic section, for assistance with the preparation of the other illustrations. 


\section{REFERENCES}

Ashbee, P 1966 'The Fussell's Lodge long barrow excavations 1957', Archaeologia, 100 (1966), 1-80.

Barber, J 1982 'The investigation of some plough-truncated features at Kinloch Farm, Collessie, in Fife', Proc Soc Antiq Scot, 112 (1982), 524-33.

Barclay, G J 1983 'Sites of the third millennium be to the first millennium ad at North Mains, Strathallan, Perthshire', Proc Soc Antiq Scot, 113 (1983), 122-281.

Barclay, G J 1984 Balfarg Riding School; fourth interim report, privately circulated paper.

Barclay, G J \& Russell-White, C (eds) forthcoming 'Excavations in the ceremonial complex of the fourth to second millennia $\mathrm{BC}$ at Balfarg/Balbirnie, Glenrothes, Fife'.

Barclay, G J \& Tolan, Myra 1990 'Trial excavation of a terrace-edge enclosure at North Mains, Strathallan, Perthshire', Proc Soc Antiq Scot, 120 (1990), 45-53.

Buckley, D, Major, H \& Milton, B 1988 'Excavation of a possible Neolithic long barrow or mortuary enclosure at Rivenhall, Essex', Proc Prehist Soc, 54 (1988), 77-91.

Coles, J \& Simpson, D D A 1965 'The excavation of a Neolithic round barrow at Pitnacree, Perthshire, Scotland', Proc Prehist Soc, 31 (1965), 34-57.

Curle, J 1911 A Roman Frontier Post and its People: the Fort of Newstead in the Parish of Melrose, Edinburgh.

Frere, S S \& Wilkes, J J 1989 Strageath: Excavations within the Roman Fort, 1973-86. London.

Hillam, J, Morgan, R A \& Tyers, I 1987 'Sapwood estimates and the dating of short ring sequences' in R G Ward (ed), Applications of Tree-Ring Studies, Oxford, 165-85. (= BAR Int Ser 333).

Hulme, P D \& Shirriffs, Jennifer 1985 'Pollen analysis of a radiocarbon-dated core from North Mains, Strathallan, Perthshire', Proc Soc Antiq Scot, 115 (1985), 105-13.

Kendrick, J 1980 Douglasmuir: the excavations of an early Iron Age settlement and a Neolithic enclosure 1979-1980: Preliminary Report, privately circulated paper.

Linge, J 1987 'Rediscovering a landscape: the barrow and motte in north Ayrshire', Proc Soc Antiq Scot, 117 (1987), 23-32.

Loveday, R 1985 Cursuses and Related Monuments of the British Neolithic. Thesis presented for the degree of PhD to the University of Leicester.

Loveday, R \& Petchey, M 1982 'Oblong ditches: a discussion and some new evidence', Aerial Archaeology, 8 (1982), 17-24.

Manby, T 1976 'Excavations of the Kilham long barrow, East Riding of Yorkshire', Proc Prehist Soc, 42 (1976), 111-59.

Manning, W H 1966 'A hoard of Romano-British ironwork from Brampton, Cumberland', Trans Cumberland Westmorland Antiq Archaeol Soc (2 ser), 56 (1966), 11-36.

Marsac, M, Scarre, C \& Riley, D 1983 'Recent Discoveries of Possible Neolithic Long Mounds in Western France and their British Parallels', Aerial Archaeol, 8 (1983), 1-16.

Masters, L 1973 'The Lochill long cairn', Antiquity, 47 (1973), 96-100.

Morgan, Faith de M 1959 'The excavation of a long barrow at Nutbane, Hants.', Proc Prehist Soc, 25 (1959), 15-51.

Morgan, R 1990 'Tree-ring studies at Haddenham', Curr Archaeol, 118 (1990), 343-4.

Phillips, C W 1935 'The excavation of the Giants' Hills long barrow, Skendleby, Lincolnshire', Archaeologia, 85 (1935), 37-106.

Piggott, S 1972 'Excavation of the Dalladies long barrow, Fettercairn, Kincardineshire', Proc Soc Antiq Scot, 104 (1971-2), 23-47.

Pitts, L F \& St Joseph, J K 1985 Inchtuthil: The Roman Legionary Fortress. London.

Ralston, I B M 1982 'A Timber Hall at Balbridie Farm', Aberdeen Univ Rev, 168 (1982), 238-49.

Schweingruber, F H 1978 Wood Anatomy. Switzerland.

Scott, J 1989 'The hall and motte at Courthill, Dalry, Ayrshire', Proc Soc Antiq Scot, 119 (1989), $271-8$.

Taylor, M 1981 Wood in Archaeology. Princes Risborough, Bucks.

Tolan, Myra 1988 Pit Circles in Scotland: Some Possible Interpretations, unpublished BA dissertation, Department of Archaeology, University of Newcastle upon Tyne.

Vyner, B 1984 'The excavation of a Neolithic cairn at Street House, Loftus, Cleveland', Proc Prehist Soc, 50 (1984), 151-95.

This paper is published with the aid of a grant from Historic Scotland 